\title{
Study on The Improvement of Essential Oil Quality and Its Repellent Activity of Betel Leaves Oil (Piper betle I.) from Indonesia
}

\author{
DANTE ALIGHIRI ${ }^{1,2 *}$, EDY CAHYONO ${ }^{1,2}$, WILLY TIRZA EDEN $^{1,2}$, \\ ERSANGHONO KUSUMA ${ }^{1,2}$ and KASMADI IMAM SUPARDI, ${ }^{1,2}$
}

\author{
'Essential Oil Study Center, Faculty of Mathematics and Natural Sciences, Universitas Negeri Semarang, \\ 50229 Central Java, Indonesia. \\ ${ }^{2}$ Chemistry Department, Faculty of Mathematics and Natural Sciences, Universitas Negeri Semarang, \\ 50229 Central Java, Indonesia. \\ ${ }^{*}$ Corresponding author E-mail: dante_alighiri@mail.unnes.ac.id
}

http://dx.doi.org/10.13005/ojc/340631

Received: July 21, 2018; Accepted: November 07, 2018)

\begin{abstract}
The study to improve the quality of Indonesia betel leaves oil is done by treatment of citric acid and sodium carbonate. The treatment showed that the iron content and acid value were reduced optimally in the addition of $5 \%(\mathrm{w} / \mathrm{w})$ citric acid $\left(12 \mathrm{~h}, 50^{\circ} \mathrm{C}\right)$ and $5 \%(\mathrm{w} / \mathrm{w})$ sodium carbonate $\left(9 \mathrm{~h}, 50^{\circ} \mathrm{C}\right)$ yielded $0.45 \mathrm{mg} / \mathrm{L}$ of iron content and $1.00 \mathrm{mg} / \mathrm{g}$ of acid value, respectively. The main component of Indonesia betel leaves oil are 4-allyl phenylacetate. The descriptive sensory analysis showed that there were differences between betel leaves oil from Bogor compared with Boyolali and Makassar. There is a significant difference that the content of betel leaves oil from Bogor contains an isoeugenol compound of $20.71 \%$ while, Boyolali and Makassar contain eugenol of 17.02 and $19.21 \%$, respectively. The study of the insect repellency indicated that Indonesia betel leaves oil potentially used as mosquito of Aedes aegypti repellent.
\end{abstract}

Keywords: Piper betle, Iron Content, Acid Value, Sensory Analysis, Insect Repellent, Aedes aegypti

\section{INTRODUCTION}

Indonesia is a potential country as a source of essential oil raw materials. Unfortunately, the source of the abundant essential oil raw material has not been maximized by the essential oil processing industry players. Indonesia has only been able to export essential oil raw materials and imports more products from the essential oil 1 . One type of essential oil of Indonesia that is potential to be developed is the betel leaves oil (Piper betle L.).

Betel leaves oil can be obtained by distillation betel leaves ${ }^{2}$ that is contain $0.7-2.6 \%$ essential oils composed mostly of phenolic and terpenoid compounds. It has been historically known

This is an Open Access article licensed under a Creative Commons license: Attribution 4.0 International (CC- BY). Published by Oriental Scientific Publishing Company @ 2018 
as traditional herbal medicine mainly as an antiseptic, the stimulant to relieve a sore throat, carminative, and expectorant. Betel leaf is also used to treat fever, cough, headache, asthma, external injuries, burns, furunculosis, eczema, and lymphangitis ${ }^{2}$. The most important compounds as antiseptic and antimicrobial in betel oil are hydroxychavicol, chavibetol, eugenol, and allylpyrocatechol. This compound is the main compound in betel leaves oil ${ }^{3-8}$.

Although, the potential benefits of betel leaves oil is large in industry, but it turns out the quality of betel leaves oil from Indonesia has not been able to meet international market standards. However, the obstacles faced by betel leaves oil growers are the quality of Indonesia betel leaves oil which produced not meet the industry standards regarding acid value, iron content, esther value, peroxide value, and active compound levels. Indonesian betel leaves oil is not accepted by the industrial market because its iron content and acid value is too high.

The primary objective of this study was to improve the quality of Indonesia betel leaves oil by reducing the amount of iron, and an acid value in betel leaves oil to match the international market standard. The challenge is in the process of treatment to reduce iron content, and acid value needs to be considered the use of natural chemicals because the industry only receives essential oil products are processed naturally. Commonly, to reduce iron content using a chelating agent such as Ethylenediaminetetraacetic acid (EDTA).

However, the essential oil industry does not accept this material as a natural material. The strategy to overcome this problem by treatment of citric acid through aeration and agitation procedure. Citric acid occurs naturally in citrus fruits that commonly. Therefore, the essential oil industry still classifies these materials in the category of natural materials. Then, to reduce acid value in the essential oil, our study using sodium carbonate. Both chemicals in the essential oil industry are still classified into natural chemicals therefore in this study will be studied the effectiveness of citric acid in decreasing of iron content, and sodium carbonate in lowering the acid value in betel leaves oil.
Besides to improve quality of Indonesia betel leaves oil, the aim of our study to test the activity of betel leaves oil particularly, the repellency, potency of betel leaves oils that possibly become mosquito repellent ${ }^{9}$. Mosquito repellent based on betel leaves oil is a potential alternative to be developed into green mosquito repellent as an effort to prevent mosquito vector that is safe for human and environment. It is urgent to develop a new mosquito repellent to control mosquito vectors that are safe for the environment and have no toxic effects on humans ${ }^{5,9-14}$. Less information is available, however, about the mosquito repellent activities of these natural and herbal-based substances. This study evaluated the repellency of natural mosquito repellents from betel leaves oil.

\section{MATERIALS AND METHODS}

\section{Material}

Betel leaves (Piper betle L.) was collected from Bogor District (West Java Province, Indonesia), Boyolali District (Central Java Province, Indonesia), and Makassar City (South Sulawesi, Indonesia). These leaves were selected and prepared before the distillation process. Other chemicals were purchased from Merck \& Co.

\section{Steam Distillation Method}

Steam distillation method is used to collect betel leaves oils. The kettle sitting on a perforated plate above the boiling water prepared to packed betel leaves (Piper betle L.). The betel leaves oils will volatilize at $100^{\circ} \mathrm{C}$ with boiling water for $6 \mathrm{~h}$ or more. The oil will be collected and separated used the separatory funnel after the steam distillation process. It can be used to separate the immiscible liquids of two layers such as oil and water. The water will be visible at the down of the separatory funnel because of a heavier density than oil. Oil was collected after water and oil separated entirely and formed into two layers. The residual of water that fused with the oil was adsorbed with sodium sulfate solid. The quantity was calculated as yields using the formula ${ }^{15,16}$.

$$
\begin{aligned}
& \% \text { Yield }=\frac{\text { Weight of Oil (g) }}{\text { Weight of Piper betle L. Leaves Taken (g) }} \times 100 \% \\
& \text { Physical Properties of Betel Leaves Oil } \\
& \text { Determination }
\end{aligned}
$$

The specific gravity, refractive index, and optical rotation of the betel leaves oil extracted from 
the betel leaves (Piper betle L.) were recorded. The specific gravity measured at 20 and $25^{\circ} \mathrm{C}$ using by the instrument of density meter Anton-Paar 4500. The refractive index measured at $20^{\circ} \mathrm{C}$ using by the instrument of automatic digital refractometer Atago RX-7000A (Alpha). The optical rotation measured at $25^{\circ} \mathrm{C}$ using by the instrument of digital polarimeter Atago Polax-2L ${ }^{15,16}$.

\section{Sensory Evaluation Selection Panelist}

Appearance, color, and odour of the respective betel leave oil were determined by organoleptic evaluation. Evaluation of the aroma component of betel leaves oil begins with the selection of panellist from Essential Oil Study Centre, Faculty of Mathematics and Natural Sciences, Universitas Negeri Semarang, Indonesia. Panellist selection was carried out using a triangular test method which aims to determine the ability of panellist candidates to distinguish aroma. Triangular tests are carried out using some standard aroma that is estimated to contain in the sample of betel leaves oil. Panellist candidates are given three sample of standard aroma, where two sample of standard aroma has different odors. Panellist are asked to choose one sample of standard aroma which has a different aroma. This test is done duplo with a smelling strip. The standard aroma used in the triangular test for the selection of panelists is eugenol (spicy), clove bud oil (warm), chavicol (phenolic), hexanal (green), 2,3-dimethyl benzofuran (tar-like note), and patchouli oil (woody). The number of panelists involved in the triangular test was 25 people. The panellist chosen were those who had the correct answer of at least $60 \%$ of the aroma standard sample. The results of this triangular test were obtained by 12 panelists who were given training before testing the sample of betel leaves oil ${ }^{17-19}$.

\section{Sensory Analysis}

A trained panellist (eight males and four females), with ages between 23 and 56 years old was used to evaluate the intensity of the main aroma attributes of betel leaves oil from Bogor, Boyolali, and Makassar. An odor profile method was used to describe the samples of betel leaves oil using the focus group method. Judges participated in one of two roundtable discussion sessions for orientation and term development. At these sessions, judges were introduced to the sample of betel leaves oil and aroma standard. Judges were asked to describe the perceived sensations regarding the quality, intensity, and time in the odor sample. During two preliminary orientation sessions of $60 \mathrm{~min}$. panelists discussed the main odor characteristics of the betel leaves oil and agreed on their use of odor attributes. During these orientation experiments, panelists evaluated different coded samples of betel leaves oil from Bogor, Boyolali, and Makassar. The group leader of panelist served to summarize, resolve confusion, and bring the group to consensus on the final terms to be used. All panelists agreed that the odour of the samples could be described using seven attributes: eugenol (spicy, sweet clove and woody; reference: $100 \%$ eugenol $=10$ ), isoeugenol (spicy, sweet, carnation, phenolic and floral; reference: $100 \%$ isoeugenol = 10), clove bud oil (warm, sweet clove, fruity and woody; reference: $100 \%$ clove bud oil =10), chavicol (phenolic and medicinal herbal; reference: $100 \%$ chavicol $=10$ ), hexanal (green, aromatics associated with newly cut-grass and leafy plants; reference: hexanal in propylene glycol, $10 \mathrm{~g} / \mathrm{L}=6$ ), 2,3-dimethyl benzofuran (tar-like, phenolic, smoky tobacco, slightly pungent with a hint black licorice drops, leather, cade oil, smoky and bacon meaty; reference: 2,3-dimethyl benzofuran in propylene glycol, $10 \mathrm{~g} / \mathrm{L}=6$ ), and patchouli oil (woody old, wood, dry, earthy and weedy balsamic, spicy, and minty; reference: $100 \%$ patchouli oil $=10$ ). Reference products of these attributes with different intensity were prepared and provided to the panel. Individual booths with controlled illumination and temperature were used in this study. Three digit numbers were used to code samples, and they were randomly offered to panelists in glass beakers of $10 \mathrm{~mL}$ with lids; samples were left $15 \mathrm{~min}$. at room temperature before analyses. The intensity of the seven odor attributes was scored using a scale from 0 to 10 , where $0=$ none or not perceptible intensity, and 10 $=$ extremely high intensity ${ }^{17-19}$.

\section{Iron Content Determination}

Iron content was determined according to the spectrophotometric method using instrument Spectrophotometer. Measurements are made at a maximum wavelength at $510 \mathrm{~nm}$ and ethanol $95 \%$ solution as blank ${ }^{15,16}$. 


\section{Acid Value Determination}

The acid value was determined by weighing of betel leaves oil and dissolved in a flask using $95 \%$ ethanol solution and phenolphthalein indicator. The free acid was then titrated with standard $0.1 \mathrm{~N}$ aqueous potassium hydroxide solution by adding the alkali drop-wise at a uniform rate of about 30 drops per minute. The content of the flask was continuously agitated. The first appearance of the pink coloration that did not fade within $10 \mathrm{sec}$. was considered the endpoint. Then, the Acid Value (AV) was calculated using the following equation ${ }^{15,16}$.

$$
\mathrm{AV}=\frac{\mathrm{V} \times \mathrm{N} \times 56.1}{\mathrm{~W}}
$$

with :

$$
\begin{array}{ll}
\mathrm{V} & =\text { The volume of potassium hydroxide used } \\
\mathrm{N} & =\text { Normality of potassium hydroxide } \\
\mathrm{W} & =\text { Weight in } \mathrm{g} \text { of the sample }
\end{array}
$$

\section{GC-MS Analysis}

Gas chromatography-mass spectrometry (GC-MS) analysis was carried out on an Agilent Technologies GC-MS instrument equipped with a GC 7890A gas chromatograph, a MS 5975C VL MSD mass spectrometer detector and provided with a HP-5MS (5\% diphenyl/95\% dimethylpolysiloxane) capillary column (30.00 m x $0.25 \mathrm{~mm}, 0.25 \mu \mathrm{m}$ film thicknesses). Analyses were carried out using hydrogen as carrier gas at a column flow rate of 0.5 $\mathrm{mL} / \mathrm{min}$. in a split mode with ratio of $100: 1,0.1 \mu \mathrm{l}$ samples were injected manually, and the following program: (a) $150^{\circ} \mathrm{C}$ for $0 \mathrm{~min}$. (b) raised at the rate of $2^{\circ} \mathrm{C} / \mathrm{min}$. to $180^{\circ} \mathrm{C}$; (c) the final rate was raised for $15^{\circ} \mathrm{C} / \mathrm{min}$. to $250^{\circ} \mathrm{C}$ and hold for $10 \mathrm{~min}$. Injector and detector temperatures were set at 275 and $275^{\circ} \mathrm{C}$, respectively. Peak areas were used for quantifying the constituent percentage in total betel leaves oil. The gas chromatograph was coupled to an Agilent 5975C VL MSD mass spectrometer detector. Injected in conditions equal to the betel leaves oil samples. The data acquisition and data processing were performed using the MSD Chemstation E.01.01.335 (Agilent) software.

\section{Repellent}

The first potential mosquito repellent of betel leaves (Piper betle L.) oils selected for this present investigation. In this study, mosquito repellency of betel leaves oil will be compared. Betel leaves oil is taken from three places in Indonesia, namely Bogor District (West Java Province), Boyolali District (Central Java Province), and Makassar City (South Sulawesi Province). Repellency test were three replicates.

\section{Preparation of Mosquitoes}

Aedes aegypti a principal vector of dengue hemorrhagic fever selected for laboratory evaluation. The colonies of these mosquitoes were cultured and maintained in the laboratory at $27 \pm 1^{\circ} \mathrm{C}$ and $85 \%$ relative humidity. The larvae fed with dog biscuits and yeast powder in the 3:1 ratio. Adult mosquitoes were provided by $10 \%$ sucrose solution and one-week-old chick for a blood meal. The mosquitoes starved for 3-4 days before the further treatment.

\section{Repellency Test Procedure}

The activity test of mosquito repellent was carried out by using the methods from Kim et al.,20 and Mulyani et al., ${ }^{21}$ with modification. This test is performed to determine the ability of betel leaves oils in rejecting mosquitoes of Aedes aegypti.

To test the potential of mosquito repellent from betel leaves oil for further application, 1 $\mathrm{g}$ of a Viscopearl formulation and $1 \mathrm{~g}$ of the oil were prepared. The repellency of the Viscopearl formulation against mosquito of Aedes aegypti was examined in chamber tests. Box $100 \times 20 \times 20 \mathrm{~cm}$ is divided into 3 parts of the chamber. The first part is a cube frame $20 \times 20 \times 20 \mathrm{~cm}$ covered with nets. The second part $60 \times 20 \times 20 \mathrm{~cm}$ is made of glass which is fenced by cardboard in one-third of the chamber. The middle hole of the chamber is $9 \mathrm{~cm}$ in diameter. Whereas, the third part has the same shape as the first part with the test material placed in a container. In the third part, there was a viscopearl and a wire net to trap the mosquitoes. This mosquito repellents test instrument was shown in Figure 1.

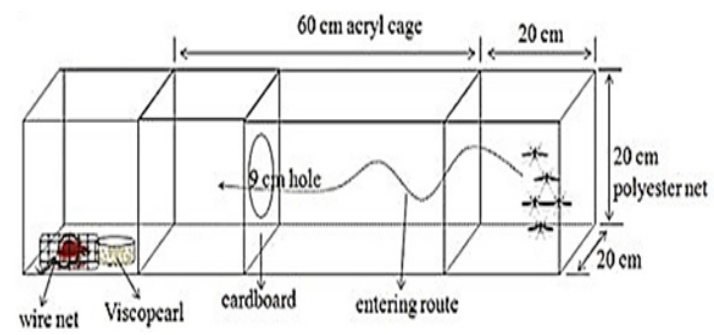

Fig. 1. Instruments Test of Mosquito Repellents

A total of $1 \mathrm{~g}$ sample of essential oils is taken and placed in $1 \mathrm{~g}$ of viscopearl. A total of 
15 Aedes aegypti mosquitoes were put into the box. Observations on repellency of betel leaves oil from three regions in Indonesia such as Bogor, Boyolali, and Makassar was performed at 5, 10, 15, 30, 45 and 60 minutes. The number of mosquitoes that migrated into the treated compartment was counted at the time period. The experiment was repeated three times for each preparation. Mosquito repellency was calculated by the following equation: \% repellency = (C-T/C) $\times 100$, where $C$ was the number of released mosquito and $\mathrm{T}$ was the number of the mosquito found in the chamber containing a mouse.

\section{Statistical Analysis}

The experimental data was performed using one-way analysis of variance (ANOVA). Data were expressed as the mean \pm standard deviation $(n=3)$. Homogenous groups and the least significant difference (LSD) were determined at the significance level of $p \leq 0.05$. All statistical analyses were performed using SPSS 24 software.

\section{RESULTS AND DISCUSSION}

The traditional way of isolating volatile compounds like essential oils from plant material is distillation. There have been three types of distillation: water distillation, water-steam distillation and steam distillation ${ }^{22}$. Some new techniques have been proposed such as supercritical fluids extraction, microwave assisted hydrodistillation, and ohmic-assisted hydrodistillation. The new techniques offer advantages such as higher extraction speeds, lower operation temperature or avoidance of organic solvents usage (which are potentially harmful in terms of environmental impact) ${ }^{23,24}$. However, in industrial scale implementations, it is preferred to use steam distillers because those imply lower initial installation costs, lower operating and maintenance costs $^{25}$. In other words, the steam distillation method is a method for essential oil extraction with a simple to implement ${ }^{26}$. Moreover, those techniques have shown to be reliable ${ }^{27}$. Therefore, the betel leaves oil from the Piper betle L. leaves was isolated by the hot steam that applied in this study. The end of steam distillation process will be condensed into the liquid. It was the mixture of oil and steam that continue separately. The proper instruments could be used it because oils were less dense than water. The betel leaves oil of Piper betle L. leaves from three places in Indonesia which represent the most abundant source of betel leaves oil namely Bogor District (West Java Province), Boyolali District (Central Java Province), and Makassar City (South Sulawesi Province) was obtained by using steam distillation methods are pale yellow to yellow when freshly distilled. This essential oil yielded varied from 0.956 to 1.04 and shown in Table 1. An analysis of variance of this place indicated that the different place had a highly significant effect on essential oil yield $(p=0.000)$. This experiment was geared to study the yield of betel leaves oil in three different areas and with respect to different environmental parameters. Along with altitude and climate parameters have shown that higher altitude also affects essential oil production due to different sunshine exposure or climate change which may account for the difference in decreasing nutrient absorption ${ }^{28}$. This might be one reason to justify the decreasing of betel leaves oil yield in Bogor recorded in the present study at higher altitudes compared to Boyolali and Makassar. Thus, it can be understood that the highest essential oil yield was obtained from Makassar cites.

Table 1:The Yield of Betel Leaves Oil (Piper betle L.) from Bogor, Boyolali, and Makassar llands

\begin{tabular}{lccc}
\hline Parameter & $\begin{array}{c}\text { Betel Leaves Oil: } \\
\text { Bogor } \\
\text { (West Java) }\end{array}$ & $\begin{array}{c}\text { Boyolali } \\
\text { (Central Java) }\end{array}$ & $\begin{array}{c}\text { Makassar } \\
\text { (South Sulawesi) }\end{array}$ \\
\hline Sample Weight $(\mathrm{kg})$ & $5.00 \pm 0.025$ & $5.10 \pm 0.010$ & $5.10 \pm 0.010$ \\
The Content of Oils $(\mathrm{g})$ & $46.85 \pm 0.010$ & $50.15 \pm 0.020$ & $53.80 \pm 0.015$ \\
Yield $(\%)^{*}$ & $0.937 \pm 0.003$ & $0.983 \pm 0.004$ & $1.055 \pm 0.006$ \\
\hline
\end{tabular}

Treatment means of the ANOVA test

Values were expressed as the mean \pm standard deviation of three replications

The mean difference is significant at the $p \leq 0.050$

* Highly significant, $p=0.000$ 


\section{Descriptive Sensory Evaluation of Betel Leaves Oil}

Based on data in Table 2, betel leaves oil produced in three regions in Indonesia such as Bogor, Boyolali, and Makassar has the same appearance that is oily liquid. Then, the betel leaves oil produced by steam distillation has a color that still conforms to the standard in the industry that yellow to brown. Moreover, it can also be observed the odour of betel leaves oil derived from the volatile oil is characteristic..

Volatiles directly affect the sensory quality of a product such as essential oil. Within the sensory quality, the aroma plays an important role of essential oils that is formed by a complex group of chemical substances, which includes aldehydes, alcohols, ketones, esters, lactones, terpenes, among other volatile compounds ${ }^{29}$.

In general, the main sensory attributes of betel leaves oil from Indonesia such as spicy, phenolic, warm, green, woody, and slightly tar-like note (Table 2). However, based on this study found the distinction between betel leaves oil from Bogor compared with Boyolali and Makassar ( $p \leq 0.05$ ). The different area in Indonesia significantly affected the intensities of the main sensory attributes of betel leaves oil. Betel leaves oil from Boyolali and Makassar have attributed aroma woody, but betel leaves oil from Bogor does not have such attributes aroma. Then, the spicy aroma of betel leaves oil from Boyolali and Makassar have a sharp aroma when compared with Bogor. Fig. 2 shows the descriptive sensory analysis profiles of different betel leaves oil samples from three regions in Indonesia such as Bogor, Boyolali, and Makassar compared with the industry standard.

Sensory data showed that betel leaves oil from Bogor was characterized by the lowest scores of those attributes related to the industry standard (spicy, 7.5; phenolic, 8.2; warm, 7.2; green, 3.3; woody, 0.5 , and tar-like, 1.5). According to the industry standard, betel leaves oil has almost similar to the standard comes from Boyolali was characterized by higher score (spicy, 9.3; phenolic, 9.7; warm, 6.6; green, 3.7; woody, 3.8, and tar-like, 1.8). While betel leaves oil from Makassar has a lower phenolic attribute (8.8) than Boyolali (9.7). However, it has the same green attribute as the industry standard (3.9) or higher than Boyolali (3.5).

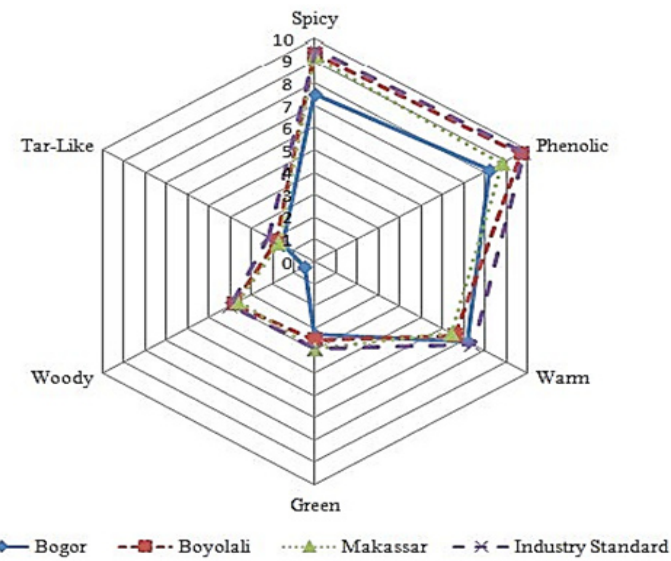

Fig. 2. Descriptive sensory analysis of aroma attributes in betel leaves oil from three regions in Indonesia such as Bogor, Boyolali, and Makassar compared with the industry standard

Thus, all the information related to descriptive sensory evaluation, which is shown, there is a distinction between betel leaves oil from Bogor compared with Boyolali and Makassar. This difference is probably caused by differences in the concentration of volatile compounds in the betel leaves oil. The concentration of these volatile compounds is generally low $(\mathrm{mg} / \mathrm{kg})$ and can be affected by a number of agronomic (variety, climatological conditions, ripening stage $)^{30,31,33}$ and technological (harvest, post-harvest treatments, storage and processing conditions) factors ${ }^{32,33}$. The different area in Indonesia while having different of soil characteristics and seasonal variations that significantly affected the intensities of the main component and sensory attributes of betel leaves oil ${ }^{33}$. It is possible, and there is a slight difference in the composition of the three betel leaves oils in Indonesia. This is a first step that will need further research, but it is a very important step, which is done by the first time and will provide very practical information for farmers and essential oil industry. To ensure it must be tested using the GC-MS instrument.

\section{Physical Properties of Betel Leaves Oil}

Study of various physicochemical characteristics explores the practical importance of essential oils in daily life. Physicochemical properties of essential oil like appearance, color, odor, specific gravity, refractive index, optical rotation, iron content, acid value, and solubility directly influence the quality of essential oil. The poor quality oil of essential oil can be early identified after analyzing these properties one. 
For example, an odor test can also use to determine what betel leaves oil is pure as original or low quality. Its to be since certain counterfeiters can be immediately identified in this way. Sensory evaluation is a simple but effective method of identifying out of place adulterated oils. Its quite quickly but remains only one to search for purity from many procedures conducted. Other, more current methods of analysis must be applied before a clear picture can be established with an oils authenticity.
The next stage is testing the physical parameters of the essential oil. It measures the specific gravity (SG), refractive index $(\mathrm{RI})$, and optical rotation (OR) before an essential oil sample gets by all of the sensory tests. This test was done to examine confirmation or rejection of oil authenticity which declared botanical species and country of origin. It possibly is revealing any adulteration with foreign materials. The physical properties of betel leave oil shown in Table 2.

Table 2: The Physical Properties of Betel Leaves Oil (Piper betle L.)

\begin{tabular}{|c|c|c|c|c|}
\hline \multirow[b]{2}{*}{ Parameter } & \multicolumn{3}{|c|}{ Betel Leaves Oil: } & \multirow[b]{2}{*}{ Industry Standard } \\
\hline & $\begin{array}{c}\text { Bogor } \\
\text { (West Java) }\end{array}$ & $\begin{array}{c}\text { Boyolali } \\
\text { (Central Java) }\end{array}$ & $\begin{array}{c}\text { Makassar } \\
\text { (South Sulawesi) }\end{array}$ & \\
\hline Appearance & Oily liquid & Oily liquid & Oily liquid & Oily liquid \\
\hline Color & Yellow & Yellow & Yellow & Yellow to brown \\
\hline Odor & $\begin{array}{c}\text { Spicy, } \\
\text { phenolic, } \\
\text { warm, green, } \\
\text { slightly woody, and } \\
\text { slightly tar-like note }\end{array}$ & $\begin{array}{c}\text { Spicy, } \\
\text { phenolic, } \\
\text { warm, green, } \\
\text { woody, and } \\
\text { slightly tar-like note }\end{array}$ & $\begin{array}{l}\text { Spicy, phenolic, } \\
\text { warm, green, } \\
\text { woody, and } \\
\text { slightly tar-like note }\end{array}$ & $\begin{array}{l}\text { Spicy, phenolic, } \\
\text { warm, green, } \\
\text { woody, and } \\
\text { slightly tar-like note }\end{array}$ \\
\hline$S G$ at $20^{\circ} \mathrm{C}$ & $0.9889 \pm 0.0003$ & $0.9879 \pm 0.0002$ & $0.9830 \pm 0.0005$ & $0.9500-1.1000$ \\
\hline$S G$ at $25^{\circ} \mathrm{C}$ & $0.9841 \pm 0.0003$ & $0.9832 \pm 0.0004$ & $0.9783 \pm 0.0007$ & $0.9400-0.9900$ \\
\hline $\mathrm{RI}$ at $20^{\circ} \mathrm{C}$ & $1.5098 \pm 0.0002$ & $1.5088 \pm 0.0001$ & $1.5091 \pm 0.0004$ & $1.4800-1.5400$ \\
\hline OR at $25^{\circ} \mathrm{C}$ & $+4.05 \pm 0.18$ & $+3.60 \pm 0.16$ & $+3.10 \pm 0.15$ & $(+) 2^{\circ}-(+) 6^{\circ}$ \\
\hline${ }^{*} \mathrm{AV}(\mathrm{mg} / \mathrm{g})$ & $12.6 \pm 0.10$ & $8.85 \pm 0.11$ & $10.13 \pm 0.03$ & Max. 5 \\
\hline \multicolumn{2}{|c|}{${ }^{*}$ Iron $(\mathrm{Fe})$ Content $(\mathrm{mg} / \mathrm{L}) 6.50 \pm 0.01$} & $7.50 \pm 0.01$ & $12.50 \pm 0.01$ & Max. 5 \\
\hline
\end{tabular}

Treatment means of the ANOVA test

Values were expressed as the mean \pm standard deviation of three replications

The mean difference is significant at the $p \leq 0.050$

* Highly significant, $p=0.000$

The SG of essential oil is one of the important criteria for determining its authenticity. Base on data in Table 2., the betel leaves oil produced from three regions in Indonesia has a specific gravity that still conforms to the standard in the industry that is $0.9500-1.1000\left(20^{\circ} \mathrm{C}\right)$ and $0.9400-0.9900\left(25^{\circ} \mathrm{C}\right)$.

Refractive index is an important physical characteristic of essential oil. The value of the refractive index varies with the wavelength of light and the temperature at which measurements are made. Based on data in Table 2., the betel leaves oil produced from three regions in Indonesia has a refractive index that still conforms to the standard in the industry that is $1.4800-1.5400\left(20^{\circ} \mathrm{C}\right)$.
Optical rotation is an important physical characteristic of an essential oil caused by the typical components of essential oil. Many essential oil constituents, in liquid state or solution, have the power to rotate the plane of polarization of plane polarized light. It is consequently exhibited by most essential oils and when expressed numerically, an optical rotation, form an important physical characteristic. Substances are called dextro- or levo, rotatory, depending on whether the plane of polarization is rotated right or left and direction of rotation is indicated by prefixing a (+) or (-) sign, respectively, to the numerical value of rotation. Based on data in Table 2., the betel leaves oil produced from three regions in Indonesia has an optical rotation that still conforms to the standard in the industry that is (+) $2^{\circ}-(+) 6^{\circ}\left(25^{\circ} \mathrm{C}\right)$. 
Table 3. The Solubility of Betel Leaves Oil (Piper betle L.)

\begin{tabular}{|c|c|c|c|c|c|}
\hline \multirow[b]{2}{*}{ Parameter } & \multicolumn{5}{|c|}{ Betel Leaves Oil: } \\
\hline & $\begin{array}{c}\text { Ratio } \\
\text { (Oil :Solvent) }\end{array}$ & $\begin{array}{c}\text { Bogor } \\
\text { (West Java) }\end{array}$ & $\begin{array}{c}\text { Boyolali } \\
\text { (Central Java) }\end{array}$ & $\begin{array}{c}\text { Makassar } \\
\text { (South Sulawesi) }\end{array}$ & $\begin{array}{l}\text { Industry } \\
\text { Standard }\end{array}$ \\
\hline & $1: 1$ & Immiscible & Immiscible & Immiscible & Immiscible \\
\hline Water & $1: 5$ & Cloudly & Cloudly & Cloudly & Cloudly \\
\hline Ethanol & $1: 1$ & Miscible & Miscible & Miscible & Miscible \\
\hline Ethanol 70\% & $1: 2$ & Miscible & Miscible & Miscible & Miscible \\
\hline Chloroform & $1: 1$ & Miscible & Miscible & Miscible & Miscible \\
\hline Ether & $1: 1$ & Miscible & Miscible & Miscible & Miscible \\
\hline Petroleum Ether & $1: 1$ & Miscible & Miscible & Miscible & Miscible \\
\hline Vegetable Oil & $1: 1$ & Miscible & Miscible & Miscible & Miscible \\
\hline Glycerol & $1: 1$ & Miscible & Miscible & Miscible & Miscible \\
\hline Propylene Glycol & $1: 1$ & Miscible & Miscible & Miscible & Miscible \\
\hline
\end{tabular}

Although six parameters have entered the industry standard, there are parameters that are important because it determines the quality of essential oil that is acid value and iron content that does not meet industry standards. The acid value of the industry standard requires a maximum of $5 \mathrm{mg} / \mathrm{g}$ as well as iron content requires a maximum of $5 \mathrm{mg} / \mathrm{L}$ in betel leaves oil. Betel leaves oil from Bogor has the highest acid value while the lowest from Boyolali. Meanwhile, the betel oil from Makassar has the highest iron content while the lowest from Bogor. This is probably caused by soil conditions and nutrients for betel plants in these three areas are different. Therefore, in this subsequent research, betel leaves oil will be treated to ensure the quality of the oil is included in the quality of industry standards.

Adulterated or improperly stored samples of essential oils quite often show a marked change in their solubility, and, as such, the determination of this property offers a convenient and rapid means for checking the authenticity of the sample. They are only slightly soluble in water and dissolve fairly well in ethanol and mixed very well with organic solvents such as chloroform and ether, vegetable oils, glycerol, and propylene glycol. The solubility of betel leaves oil shown in Table 3.

\section{Chemical Composition of Betel Leaves Oil}

The combination of GC-MS allows rapid identification of essential oil components, provided that these compounds are already known and their mass spectra available in a library. According to the data of GC-MS analysis, we investigated essential oil in Piper betle L. leaves consist mostly of phenolic and terpenoid compounds. The qualitative and quantitative betel leaves oil compositions are presented in Table 4. Compounds are listed in order of their elution on the HP-5MS column. About 43 components were identified in essential oil isolated from Piper betle L. leaves. The main component of betel leaves oil from three regions in Indonesia such as Bogor, Boyolali, and Makassar are 4-allyl phenylacetate has yielded $17.75,21.11$, and $17.08 \%$, respectively.

However, there is a significant difference that the content of betel leaves oil from Bogor contains an isoeugenol compound of 20.71 and only $0.17 \%$ eugenol while, betel leaves oil from Boyolali and Makassar does not contain isoeugenol compounds but contains large eugenol of 17.02 and $19.21 \%$, respectively. It shows that the type of betel plant from Bogor is different from the area in Boyolali and Makassar. On chromatogram also clearly visible that betel leaves oil from Bogor to have different content within the area of Boyolali and Makassar. The Chromatogram of betel leaves oil from three regions in Indonesia shown in Fig.3a, b, and c.

Each country even each region will have a distinctive type of betel leaves oil, called chemotypes. Differences chemotype such as chavicol, germacrene $\mathrm{D}^{34}$, isoeugenol, chavibetol ${ }^{35}$, eugenol, anethole ${ }^{36}$, and safrole chemotype ${ }^{37}$. In the present study, betel leaves oil obtained from the leaf of Piper betle $\mathrm{L}$. from Bogor included isoeugenol chemotype while betel leaves oil from Boyolali and Makassar included eugenol chemotype. Such chemotypic variations have been reported in most of the essential oils due to ecological and geographical conditions, age of the plant and time of harvesting ${ }^{38}$. 


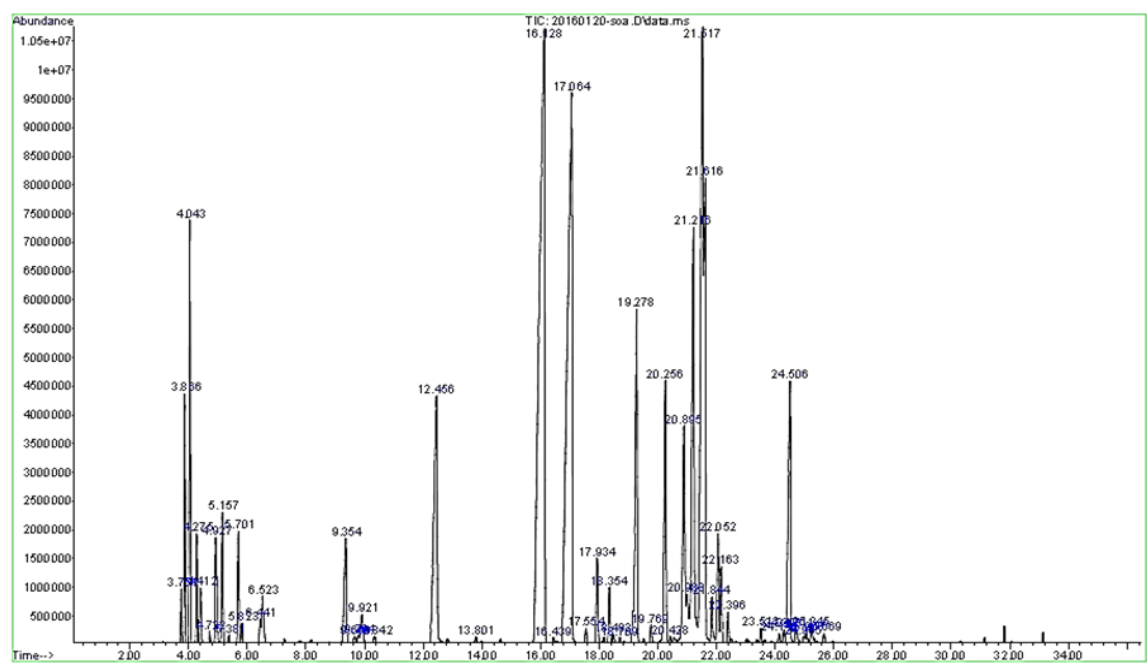

(a)

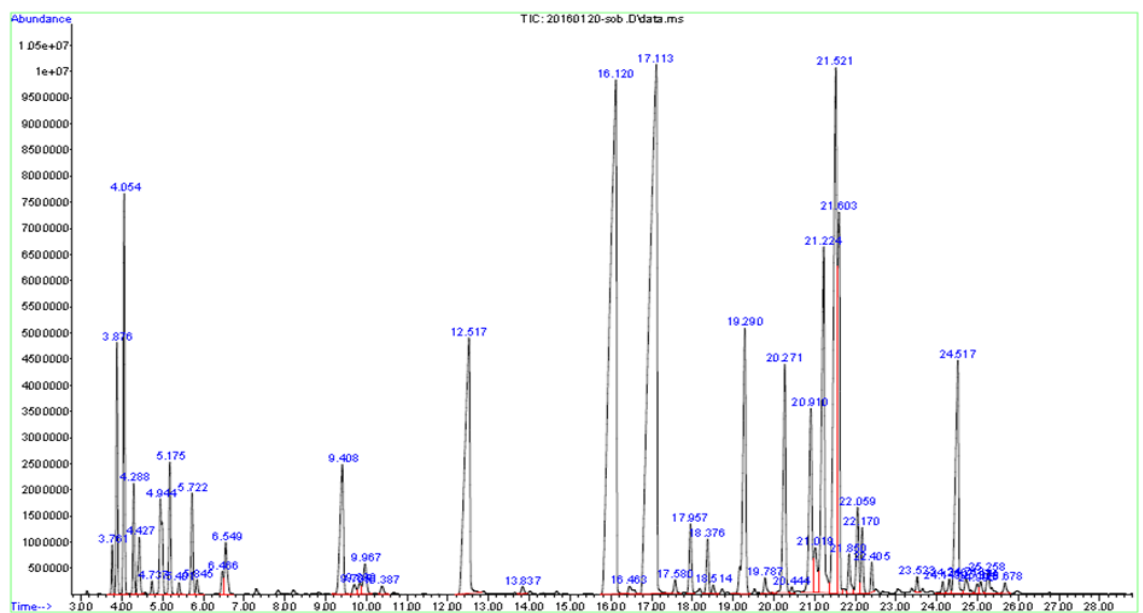

(b)

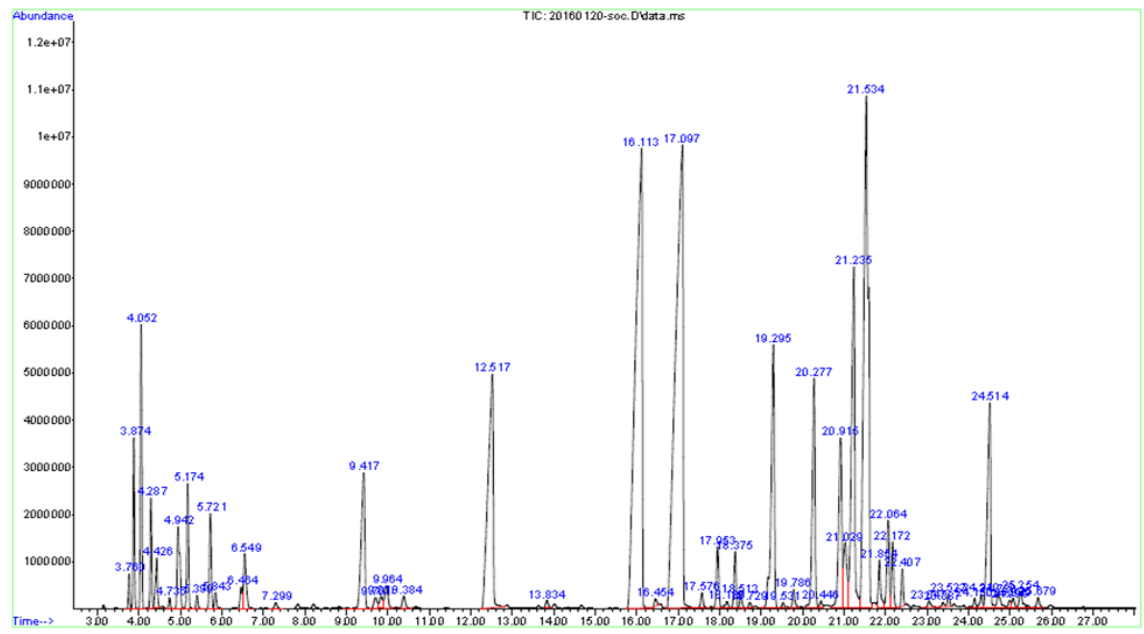

(c)

Fig. 3. Chromatogram of Betel Leaves Oil from (a) Bogor (West Java); (b) Boyolali (Central Java); (c) Makassar (South Sulawesi) 
Table 4: Chemical Compositions of Betel Leaves Oil (Piper betle L.) from Bogor, Boyolali, and Makassar

\begin{tabular}{|c|c|c|c|c|c|c|}
\hline \multirow[t]{3}{*}{ Compoud } & \multicolumn{6}{|c|}{ Betel Leaves Oil: } \\
\hline & \multicolumn{2}{|c|}{ Bogor } & \multicolumn{2}{|c|}{ Boyolali } & \multicolumn{2}{|c|}{ Makassar } \\
\hline & RTa (min.) & $\operatorname{PAb}(\%)$ & $\mathrm{RTa}$ (min. & PAb (\%) & RTa (min. & PAb (\%) \\
\hline$\alpha$-thujene & 3.761 & 0.34 & 3.750 & 0.34 & 3.761 & 0.26 \\
\hline$\alpha$-pinene & 3.874 & 1.78 & 3.863 & 1.57 & 3.874 & 1.33 \\
\hline 2,2-dimethyl-3-methylenenorbornane & 4.052 & 3.01 & 4.042 & 2.87 & 4.053 & 2.34 \\
\hline Sabinene & 4.290 & 0.83 & 4.274 & 0.73 & 4.285 & 0.90 \\
\hline$\beta$-myrcene & 4.425 & 0.61 & 4.414 & 0.55 & 4.425 & 0.58 \\
\hline$\alpha$-phellandrene & 4.738 & 0.11 & 4.722 & 0.09 & 4.739 & 0.10 \\
\hline$\alpha$-terpinene & 4.944 & 1.38 & 4.927 & 1.26 & 4.944 & 1.23 \\
\hline$\beta$ - phellandrene & 5.176 & 1.19 & 5.154 & 1.05 & 5.176 & 1.24 \\
\hline$\beta$ - ocimene & 5.403 & 0.10 & 5.381 & 0.07 & 5.398 & 0.13 \\
\hline$\gamma$-terpinene & 5.722 & 0.99 & 5.700 & 0.98 & 5.722 & 1.02 \\
\hline Terpineol & 5.846 & 0.15 & 5.824 & 0.19 & 5.841 & 0.18 \\
\hline$\alpha$-terpinolene & 6.467 & 0.23 & 6.440 & 0.23 & 6.462 & 0.24 \\
\hline Linalool & 6.548 & 0.71 & 6.521 & 0.64 & 6.548 & 0.84 \\
\hline p-men-th-1-en-4-ol & 9.406 & 2.3 & 9.352 & 1.60 & 9.417 & 2.77 \\
\hline Methyl salicylate & 9.703 & 0.16 & 9.660 & 0.11 & 9.703 & 0.20 \\
\hline$\alpha$-terpineol & 9.838 & 0.17 & 9.795 & 0.12 & 9.838 & 0.21 \\
\hline Estragole & 9.968 & 0.52 & 9.919 & 0.45 & 9.962 & 0.43 \\
\hline Capraldehyde & 10.389 & 0.12 & 10.340 & 0.11 & 10.384 & 0.20 \\
\hline Chavicol & 12.517 & 6.64 & 12.458 & 5.39 & 12.517 & 6.76 \\
\hline m-allylpyrocatechin methylene ether & 13.835 & 0.10 & 13.803 & 0.09 & 13.835 & 0.11 \\
\hline 4-allyl phenyl acetate & 16.120 & 17.75 & 16.126 & 21.11 & 16.115 & 17.08 \\
\hline Eugenol & 16.461 & 0.17 & 16.439 & 17.02 & 16.455 & 19.21 \\
\hline Isoeugenol & 17.114 & 20.71 & $-^{c}$ & $-^{c}$ & $-^{c}$ & $-c$ \\
\hline 4-(methylamino) phenol & 17.579 & 0.17 & 17.552 & 0.16 & 17.574 & 0.20 \\
\hline$\alpha$-copaene & 17.957 & 0.83 & 17.935 & 0.90 & 17.952 & 0.79 \\
\hline$\beta$-elemene & 18.378 & 0.61 & 18.351 & 0.56 & 18.373 & 0.70 \\
\hline Lauraldehyde & 18.514 & 0.10 & 18.492 & 0.09 & 18.514 & 0.16 \\
\hline$\beta$-caryophyllene & 19.291 & 4.13 & 19.280 & 4.64 & 19.297 & 4.67 \\
\hline$\alpha$-bergamotene & 19.788 & 0.20 & 19.767 & 0.20 & 19.788 & 0.24 \\
\hline$\alpha$-humulene & 20.269 & 3.03 & 20.258 & 3.22 & 20.275 & 3.52 \\
\hline Aromadendrene & 20.442 & 0.07 & 20.426 & 0.07 & 20.448 & 0.09 \\
\hline Gamma-muurolene & 20.912 & 2.84 & 20.896 & 3.02 & 20.917 & 3.07 \\
\hline Germacrene D & 21.020 & 0.75 & $-^{c}$ & $-^{c}$ & 21.031 & 1.25 \\
\hline$\alpha$-curcumene & $-{ }^{c}$ & $-^{c}$ & 20.987 & 0.69 & $-^{c}$ & $-^{c}$ \\
\hline$\beta$-selinene & 21.225 & 5.52 & 21.214 & 6.37 & 21.236 & 6.19 \\
\hline AcetylEugenol & 21.522 & 9.62 & 21.517 & 10.23 & 21.533 & 13.09 \\
\hline Acetyllsoeugenol & 21.603 & 3.96 & 21.614 & 5.41 & $-^{c}$ & $-^{c}$ \\
\hline$\beta$-bisabolene & 21.852 & 0.50 & 21.846 & 0.52 & 21.852 & 0.65 \\
\hline$\alpha$-panasinsen & 22.057 & 1.10 & 22.052 & 1.22 & 22.063 & 1.23 \\
\hline$\delta$-cadinene & 22.171 & 0.72 & 22.165 & 0.74 & 22.171 & 0.78 \\
\hline$\gamma$-bisabolene & 22.403 & 0.29 & 22.397 & 0.26 & 22.408 & 0.40 \\
\hline Germacrene B & $-^{c}$ & $-^{c}$ & $-^{c}$ & $-^{c}$ & 23.046 & 0.10 \\
\hline Spathulenol & $--^{c}$ & $-^{c}$ & $-^{c}$ & $-^{c}$ & 23.386 & 0.07 \\
\hline$\beta$-caryophyllene epoxide & 23.521 & 0.16 & 23.510 & 0.13 & 23.521 & 0.15 \\
\hline$\gamma$-gurjunene & 24.310 & 0.17 & 24.299 & 0.15 & 24.310 & 0.19 \\
\hline 4-allyl-1,2-diacetoxybenzene & 24.515 & 3.86 & 24.504 & 3.83 & 24.515 & 3.70 \\
\hline Tau-muurolol & 24.996 & 0.12 & 24.985 & 0.08 & 24.996 & 0.10 \\
\hline Total & & 98.82 & & 99.06 & & 98.70 \\
\hline
\end{tabular}

${ }^{\text {aRetention time. }}$

bPick area.

cNot detected compounds. 
Improvement of The Quality of Betel Leaves Oil Using Natural Reagent

These differences in iron contents could be ascribed to a well-supplied soil and nutrient for betel plants in Bogor, Boyolali, and Makassar. Betel leaves oil from Bogor has the highest acid value while the lowest from Boyolali. Meanwhile, the betel oil from Makassar has the highest iron content while the lowest from Bogor. Therefore, in our research, betel leaves oil will be treated with a natural chelating agent like citric acid to ensure the quality of the oil is included in the quality of industry standards. Based on data in the Table 5., showed that Iron content of the betel leaves oil after purification with citric acid lower than before purification and the lowest with citric acid that 5 and $6 \%$ (w/w) applicated. However, taking into account the effectiveness to be applied in the industry, the optimum of citric acid concentration is an addition of $5 \%(\mathrm{w} / \mathrm{w})$ and time of agitation and aeration with the reaction temperature at $50^{\circ} \mathrm{C}$ is 12 hours. In the optimum conditions, iron content in betel leaves oil from three regions in Indonesia such as Bogor, Boyolali, and Makassar can be significantly decreased, i.e., concentrations of iron content, initially
$6.50 \pm 0.01,7.50 \pm 0.01$, and $12.50 \pm 0.01 \mathrm{mg} / \mathrm{L}$ to $0.45 \pm 0.050,0.50 \pm 0.050$, and $0.55 \pm 0.057 \mathrm{mg} / \mathrm{L}$, respectively. These treatments are fulfilled at industry standard that is require maximum iron content in betel leaves oil at $5 \mathrm{mg} / \mathrm{L}$. It can be concluded that citric acid is a natural chelating agent which is active to absorb iron content in betel leaves oil.

A part of the volatile oil is having less amount of free organic acid content that bonded naturally or produced from the oxidation process, and ester hydrolyze. Oil that has been dried and protected from light and air is having less amount of free organic acid. The decreasing reaction of an acid amount is caused by the existence of acid and alcohol in betel leaves oil component above. In our research, the treatment for decreasing acid value used by a natural agent such sodium carbonate succeed effectively. The Table 6 showed an acid value of betel leaves oil is lower after treatment with sodium carbonate $\left(\mathrm{Na}_{2} \mathrm{CO}_{3}\right)$ and the optimum of $\mathrm{Na}_{2} \mathrm{CO}_{3}$ concentration is an addition of $5 \%(\mathrm{w} / \mathrm{w})$ and time of agitation and aeration with the reaction temperature of $50^{\circ} \mathrm{C}$ is 9 hours.

Table 5: Iron Content of The Betel Leaves Oil (Piper betle L.) from Bogor, Boyolali, and Makassar after Purification with Citric Acid at Reaction Temperature of $50^{\circ} \mathrm{C}$

\begin{tabular}{|c|c|c|c|c|}
\hline \multirow[t]{2}{*}{ Sample $^{1}$} & \multirow{2}{*}{$\begin{array}{l}\text { Time of Agitation } \\
\text { and (hours) }\end{array}$} & \multicolumn{3}{|c|}{ AerationIron Content in Betel Leaves Oil (mg/L) } \\
\hline & & $\begin{array}{c}\text { Bogora }^{a} \\
\text { (West Java) }\end{array}$ & $\begin{array}{c}\text { Boyolali } \\
\text { (Central Java) }\end{array}$ & $\begin{array}{c}\text { Makassarc }^{c} \\
\text { (South Sulawesi) }\end{array}$ \\
\hline $\begin{array}{l}\text { Betel Leaves Oil } \\
1 \% \text { Citric Acid }\end{array}$ & $\begin{array}{c}3 \\
6 \\
9 \\
12\end{array}$ & $\begin{array}{l}6.00 \pm 0.100 \\
5.80 \pm 0.100 \\
2.03 \pm 0.057 \\
1.87 \pm 0.057\end{array}$ & $\begin{array}{l}6.50 \pm 0.100 \\
6.03 \pm 0.057 \\
2.47 \pm 0.057 \\
2.17 \pm 0.057\end{array}$ & $\begin{array}{c}11.20 \pm 0.100 \\
6.17 \pm 0.057 \\
2.67 \pm 0.057 \\
2.47 \pm 0.057\end{array}$ \\
\hline $\begin{array}{l}\text { Betel Leaves Oil } \\
2 \% \text { Citric Acid }\end{array}$ & $\begin{array}{c}3 \\
6 \\
9 \\
12\end{array}$ & $\begin{array}{l}5.00 \pm 0.100 \\
4.03 \pm 0.057 \\
2.00 \pm 0.100\end{array}$ & $\begin{array}{l}5.00 \pm 0.100 \\
4.20 \pm 0.100 \\
2.00 \pm 0.100\end{array}$ & $\begin{array}{l}5.07 \pm 0.057 \\
4.30 \pm 0.100 \\
2.30 \pm 0.100\end{array}$ \\
\hline $\begin{array}{l}\text { Betel Leaves Oil } \\
3 \% \text { Citric Acid }\end{array}$ & $\begin{array}{c}3 \\
6 \\
9 \\
12\end{array}$ & $\begin{array}{l}2.30 \pm 0.100 \\
2.13 \pm 0.057 \\
1.97 \pm 0.057\end{array}$ & $\begin{array}{l}2.43 \pm 0.057 \\
2.30 \pm 0.100 \\
2.00 \pm 0.100\end{array}$ & $\begin{array}{l}2.60 \pm 0.100 \\
2.37 \pm 0.057 \\
2.17 \pm 0.057\end{array}$ \\
\hline $\begin{array}{l}\text { Betel Leaves Oil } \\
4 \% \text { Citric Acid }\end{array}$ & $\begin{array}{c}3 \\
6 \\
9 \\
12\end{array}$ & $\begin{array}{l}1.93 \pm 0.057 \\
1.87 \pm 0.057 \\
1.43 \pm 0.057\end{array}$ & $\begin{array}{l}2.07 \pm 0.057 \\
1.90 \pm 0.100 \\
1.50 \pm 0.100\end{array}$ & $\begin{array}{l}2.03 \pm 0.115 \\
2.00 \pm 0.100 \\
1.73 \pm 0.057 \\
1.57 \pm 0.057\end{array}$ \\
\hline $\begin{array}{l}\text { Betel Leaves Oil } \\
5 \% \text { Citric Acid }\end{array}$ & $\begin{array}{c}3 \\
6 \\
9 \\
12\end{array}$ & $\begin{array}{l}1.82 \pm 0.029 \\
1.33 \pm 0.050 \\
1.02 \pm 0.029 \\
0.45 \pm 0.050\end{array}$ & $\begin{array}{l}1.90 \pm 0.057 \\
1.55 \pm 0.050 \\
1.15 \pm 0.050\end{array}$ & $\begin{array}{l}2.00 \pm 0.100 \\
1.80 \pm 0.050 \\
1.20 \pm 0.057 \\
0.55 \pm 0.057\end{array}$ \\
\hline $\begin{array}{l}\text { Betel Leaves Oil } \\
6 \% \text { Citric Acid }\end{array}$ & $\begin{array}{c}1 \\
3 \\
6 \\
9 \\
12\end{array}$ & $\begin{array}{l}1.80 \pm 0.050 \\
1.23 \pm 0.076 \\
0.50 \pm 0.050 \\
0.45 \pm 0.029\end{array}$ & $\begin{array}{l}1.87 \pm 0.050 \\
1.50 \pm 0.100 \\
1.10 \pm 0.100 \\
0.50 \pm 0.076\end{array}$ & $\begin{array}{l}1.90 \pm 0.100 \\
1.80 \pm 0.100 \\
1.20 \pm 0.100 \\
0.55 \pm 0.100\end{array}$ \\
\hline
\end{tabular}

Treatment means of the ANOVA test.

Values were expressed as the mean \pm standard deviation of three replications.

The mean difference is significant at the $p \leq 0.050$.

${ }^{1}$ Means are significantly different in the different time of agitation and aeration $\left({ }^{a} p=0.000 ;{ }^{b} p=\right.$ $0.000 ;{ }^{c} p=0.000$ ).

${ }^{2}$ Means are significantly different in the different concentration of citric acid $\left({ }^{a} p=0.000 ;{ }^{b} p=0.000\right.$; $\left.{ }^{c} p=0.000\right)$. 
Table 6: Acid Value of The Betel Leaves Oil (Piper betle L.) from Bogor, Boyolali, and Makassar after Treatment with $\mathrm{Na}_{2} \mathrm{CO}_{3}$ at Reaction Temperature of $50^{\circ} \mathrm{C}$

\begin{tabular}{|c|c|c|c|c|}
\hline \multirow[t]{2}{*}{ Sample $^{1}$} & \multirow{2}{*}{$\begin{array}{l}\text { Time of Agitation } \\
\text { and (hours) })^{2}\end{array}$} & \multicolumn{3}{|c|}{ AerationAcid Value in Betel Leaves Oil (mg/g) } \\
\hline & & $\begin{array}{c}\text { Bogora } \\
\text { (West Java) }\end{array}$ & $\begin{array}{c}\text { Boyolalib } \\
\text { (Central Java) }\end{array}$ & $\begin{array}{c}\text { Makassarc } \\
\text { (South Sulawesi) }\end{array}$ \\
\hline Betel Leaves Oil & 3 & $10.57 \pm 0.025$ & $7.52 \pm 0.030$ & $9.34 \pm 0.030$ \\
\hline \multirow[t]{3}{*}{$1 \% \mathrm{Na}_{2} \mathrm{CO}_{3}$} & 6 & $9.50 \pm 0.020$ & $6.50 \pm 0.030$ & $8.00 \pm 0.085$ \\
\hline & 9 & $7.74 \pm 0.030$ & $6.04 \pm 0.040$ & $7.80 \pm 0.030$ \\
\hline & 12 & $6.60 \pm 0.020$ & $5.60 \pm 0.030$ & $5.43 \pm 0.040$ \\
\hline Betel Leaves Oil & 3 & $8.70 \pm 0.030$ & $6.00 \pm 0.100$ & $7.50 \pm 0.030$ \\
\hline \multirow{3}{*}{$2 \% \mathrm{Na}_{2} \mathrm{CO}_{3}$} & 6 & $7.75 \pm 0.060$ & $5.85 \pm 0.040$ & $6.55 \pm 0.041$ \\
\hline & 9 & $6.30 \pm 0.030$ & $4.10 \pm 0.015$ & $5.44 \pm 0.030$ \\
\hline & 12 & $5.60 \pm 0.030$ & $4.00 \pm 0.025$ & $4.50 \pm 0.020$ \\
\hline Betel Leaves Oil & 3 & $8.45 \pm 0.040$ & $5.85 \pm 0.030$ & $6.33 \pm 0.040$ \\
\hline \multirow{3}{*}{$3 \% \mathrm{Na}_{2} \mathrm{CO}_{3}$} & 6 & $7.24 \pm 0.046$ & $5.04 \pm 0.040$ & $5.12 \pm 0.026$ \\
\hline & 9 & $5.34 \pm 0.046$ & $4.00 \pm 0.062$ & $4.10 \pm 0.092$ \\
\hline & 12 & $4.10 \pm 0.101$ & $3.50 \pm 0.030$ & $3.00 \pm 0.100$ \\
\hline Betel Leaves Oil & 3 & $6.20 \pm 0.030$ & $4.50 \pm 0.050$ & $5.10 \pm 0.098$ \\
\hline \multirow[t]{3}{*}{$4 \% \mathrm{Na}_{2} \mathrm{CO}_{3}$} & 6 & $5.50 \pm 0.030$ & $4.00 \pm 0.050$ & $4.30 \pm 0.050$ \\
\hline & 9 & $3.55 \pm 0.030$ & $2.05 \pm 0.046$ & $2.35 \pm 0.100$ \\
\hline & 12 & $2.20 \pm 0.046$ & $1.10 \pm 0.030$ & $1.20 \pm 0.030$ \\
\hline Betel Leaves Oil & 3 & $5.00 \pm 0.050$ & $4.00 \pm 0.088$ & $4.20 \pm 0.046$ \\
\hline \multirow{3}{*}{$5 \% \mathrm{Na}_{2} \mathrm{CO}_{3}$} & 6 & $4.10 \pm 0.098$ & $3.00 \pm 0.060$ & $3.50 \pm 0.060$ \\
\hline & 9 & $1.00 \pm 0.050$ & $1.00 \pm 0.100$ & $1.00 \pm 0.115$ \\
\hline & 12 & $1.00 \pm 0.050$ & $1.00 \pm 0.050$ & $1.00 \pm 0.050$ \\
\hline Betel Leaves Oil & 3 & $4.60 \pm 0.050$ & $3.85 \pm 0.100$ & $4.40 \pm 0.050$ \\
\hline \multirow[t]{3}{*}{$6 \% \mathrm{Na}_{2} \mathrm{CO}_{3}$} & 6 & $4.10 \pm 0.106$ & $3.00 \pm 0.050$ & $3.60 \pm 0.060$ \\
\hline & 9 & $1.00 \pm 0.050$ & $1.00 \pm 0.040$ & $1.00 \pm 0.040$ \\
\hline & 12 & $1.00 \pm 0.050$ & $1.00 \pm 0.050$ & $1.00 \pm 0.050$ \\
\hline
\end{tabular}

Treatment means of the ANOVA test.

Values were expressed as the mean \pm standard deviation of three replications.

The mean difference is significant at the $p \leq 0.050$.

${ }^{1}$ Means are significantly different in the different time of agitation and aeration $\left({ }^{a} p=0.000 ;{ }^{b} p=0.000 ;{ }^{c} p=0.000\right)$.

${ }^{2}$ Means are significantly different in the different concentration of $\mathrm{Na}_{2} \mathrm{CO}_{3}\left({ }^{\mathrm{a}} \mathrm{p}=0.000\right.$; ${ }^{b} p=0.000 ;{ }^{c} p=0.000$ ).

\section{Repellent Effect of Betel Leaves Oil}

Research on mosquito repellents has focused, in part, on the impact of agricultural products, promoting the development of natural plant-based mosquito repellents. Essential oils from such plants as Piper betle L. leaves have been shown effective at repelling mosquitoes. The main component of Indonesia betel leaves oils are 4-allyl phenylacetate and the other main components only different of one compound, namely isoeugenol (Bogor) and eugenol
(Boyolali and Makassar). The main components are included in the class of phenolic compounds. Thus, it appears that repellency of Indonesia betel leaves oil due to the presence of phenolic compounds. Thus, assessment of betel leaves oil's repellency should include the testing which may have very effective repellents.

The mosquito repellency of this active component shown in Table 7. Based on the 
Table 7., the repellent activity of betel leaves oil from three regions in Indonesia such as Bogor, Boyolali, and Makassar was measured by the protection period against the bites of Aedes aegypti during 1 hour. Each percent repellency value represents percent for the number of mosquitoes that do not leave from the Viscopearl. Viscopearl was treated with betel leaves oil and the control was used by Viscopearl which was not treated with oil but replaced with ethanol. The result showed that is no significant difference ( $p>0.050)$ with the repellency betel leaves oil in three regions in Indonesia. Although, this data indicated that betel leaves oil potentially used as mosquito repellent. The repellency of betel leaves oil Indonesia from such as Bogor, Boyolali, and Makassar provided 71.59 $\pm 0.46,72.98 \pm 0.13$, and $72.27 \pm 0.16 \%$, respectively for $1 \mathrm{~h}$ against mosquito of Aedes aegypti. These repellency results was not much different from the repellency of N,N-diethylm-toluamide (82\%), C. cassia bark extracts ( $91 \%)$, C. camphora steam distillate $(94 \%)$ for $1 \mathrm{~h}$ against mosquito of Aedes aegypti3, the Guatemalan lemongrass oil (74\%) for $2.5 \mathrm{~h}$ against Anopheles darlingi and $95 \%$ protection for $2.5 \mathrm{~h}$ against Mansonia $s_{p} p^{40}$.

Table 7:The Mosquito Repellent Test Result of Betel Leaves Oil (Piper betle L.)

\begin{tabular}{lcccccc}
\hline $\begin{array}{l}\text { Assay of Betel } \\
\text { Leaves Oil from: }\end{array}$ & \multicolumn{5}{c}{ \% Repellency Percentage per Minutes } & \\
$5^{\mathrm{a}}$ & $10^{\mathrm{b}}$ & $15^{\mathrm{c}}$ & $30^{\mathrm{d}}$ & $45^{\mathrm{e}}$ & $60^{f}$ \\
\hline Bogor $^{3}$ & $86.95 \pm 0.16$ & $85.79 \pm 0.49$ & $84.71 \pm 0.15$ & $84.04 \pm 0.31$ & $72.00 \pm 0.68$ & $71.59 \pm 0.46$ \\
Boyolali $^{3}$ & $87.33 \pm 0.07$ & $86.67 \pm 0.13$ & $85.51 \pm 0.30$ & $84.50 \pm 0.10$ & $73.26 \pm 0.48$ & $72.98 \pm 0.13$ \\
Makassar $^{3}$ & $87.11 \pm 0.19$ & $85.87 \pm 0.40$ & $84.97 \pm 0.44$ & $84.37 \pm 0.09$ & $72.85 \pm 0.30$ & $72.27 \pm 0.16$ \\
\hline
\end{tabular}

\section{CONCLUSION}

Indonesia betel leaves oil process was a steam distillation of Piper betle L. leaves. The main sensory attributes such as spicy, phenolic, warm, green, woody, and slightly tar-like note. The main component is 4-allyl phenylacetate. There is a significant difference that betel leaves oil from Bogor included isoeugenol chemotype while betel leaves oil from Boyolali and Makassar included eugenol chemotype. Improving the quality of Indonesia betel leaves oil is done by treatment of citric acid and sodium carbonate. There is no significant difference in repellent activity of betel leaves oil from three regions in Indonesia such as Bogor, Boyolali, and Makassar. Although, this data indicated that betel leaves oil potentially used as mosquito repellent.

\section{ACKNOWLEDGMENT}

This research was funded by The Ministry of Research, Technology and the Higher Education Republic of Indonesia and DIPA FMIPA Universitas Negeri Semarang.

\section{REFERENCES}

1. Alighiri, D.; Eden, W. T.; Supardi, K. I.; Masturi; Purwinarko, A. IOP Conf. Ser.: J. Phys.: Conf. Ser., 2017, 8, 24012021.

2. Rekha, V.P.B.; Kollipara, M.; Gupta, B.R.S.S.S.; Bharath, Y; Pulicherla, K.K. Am. J. Ethnomedicine., 2014, 5, 276-289.

3. Vandana, D.; Tripathi, S. J. Pharmacogn. Phytochem., 2014, 4, 93-98.

4. Sugumaran, M.; Poornima, M.; Venkatraman, S.; Lakshmi, M.; Srinivasansethuvani. J. Pharm. Res., 2011, 10, 3424-3426.

5. Trade Policy Analysis and Development Agency (TRECYDA). Indonesian Essential Oil: The Scents of Natural Life. Handbook of Commodity Profile Trade Policy Analysis and Development Agency., 2011.
6. Bajpai, V.; Sharma, D.; Kumar, B.; Madhusudanan, K.P. Chromatography., 2010, 24, 1283-1286.

7. Basak, S.; Guha, P. Int. J. Food Microbiol., 2015, 215, 171-178.

8. Khan, M. Orient. J. Chem., 2015, 31, 541545.

9. Prabodh, S.; William, S. N. L. Int. J. Prof. Holist. Aromather., 2012, 1, 23-26.

10. Das, N.G.; Baruah, I.; Talukdar, P.K.; Das, S.C. J. Vector. Borne. Dis., 2003, 40, 49-53.

11. Abdel-Rahman, A.; Shetty, A.K.; Abou-Donia, M.B. Exp. Neurol., 2001, 172, 153-171.

12. Islam, J.; Zaman, K.; Duaraha, S.; Rajua, P. S.; Chattopadhyay, P. Acta Trop., 2017, 167, 216-230. 
13. Alimi, T.O.; Qualls, W.; A Roque, D.D.; Naranjo, D.P.; Samson, D.M.; Beier, J.C.; Xue, R.-D. J. Am. Mosq. Control Assoc., 2013, 29, 49-53.

14. Chattopadhyay, P.; Dhiman, S.; Borah, S.; Rabha, B.; Chaurasia, A.K.; Veer, V. Acta Trop., 2015, 147, 45-53.

15. Association of Official Analytical Chemists (AOAC). Official methods of analysis of the Association of Official Analytical Chemists, 16.ed.; Arlington, AOAC., 1995.

16. American Society for Testing and Materials (ASTM). Standard test method for density and relative density of crude oils by digital density analyzer. D5002. In: Annual Book of ASTM Standards; West Conshohocken, ASTM., 1999.

17. S Meilgaard M.; Civille G. V.; Carr B. T. Sensory Evaluation Techniques, 4th ed.; Boca Raton, FL. CRC Press., 2007.

18. Stone H.; Sidel J. L. Sensory Evaluation Practices, 3rd ed; San Diego, CA., Elsevier Academic Press., 2004.

19. Calín-Sánchez, Á.; Figiel, A.; Lech, K.; Szumny, A.; Carbonell-Barrachina, Á. A. Dry. Technol. 2013, 31, 224-235.

20. Kim, S-I; Yoon, J-S; Baeck, S-J; Lee, S-H; Ahn, Y. J.; Kwon, H. W. Journal of Medical Entomology., 2012, 4, 876-885.

21. Mulyani, S.; Mulyaningsih, B.; Lestari, A. W.; Fitri, A. M.; Anna, D. S. Trad.med. J., 2013, 3, 195-200.

22. Chemat, F.; Boutekedjiret, C.Reference Module in Chemistry, Molecular Sciences and Chemical Engineering: Extraction//Steam Distillation; Elsevier BV., 2015.

23. Arranz, E.; Jaime, L.; L'opez de las Hazas, M. C.; Reglero, G.; Santoyo, S. Ind. Crops Prod., 2015, 67, 121-129.

24. Hashemi, S. M. B.; Nikmaram, N.; Esteghlal, S.; Khaneghah, A. M.; Niakousari, M.; Barba, F. J.;
Roohinejad, S.; Koubaa, M., 2017. Innov. Food Sci. Emerg. Technol., 2017, 41, 172-178.

25. Masango, P. J. Clean. Prod., 2005, 13, 833-839.

26. Reverchon E.; Senatore F. Flavour Fragr. J., 1992, 7, 227-230.

27. Burt, S. Int. J. Food Microbiol., 2004, 94, 223-253.

28. Khorshidi, J.; Tabatabaie, M. F.; Omidbaigi, R.; Sefidkon, F. J. Agric. Sci., 2009, 1, 152-157.

29. Alonso, A.; Vázquez-Araújo, L.; GarcíaMartínez, S.; Ruiz, J.J.; Carbonell-Barrachina, A.A. Eur. Food Res. Technol., 2009, 230, 315-323.

30. Melgarejo, P.; Calín-Sánchez, A.; Hernández, F.; Szumny, A.; Martínez, J.J.; Legua, P.; Martínez, R.; Carbonell-Barrachina, A.A. Sci. Hort., 2012, 134, 114-120.

31. Vendramini, A.L.; Trugo, L.C. Food Chem., 2000, 71, 195-198.

32. Gironés-Vilaplana, A.; Calín-Sánchez, Á.; Moreno, D.A.; Carbonell-Barrachina, Á.A.; García-Viguera, C. Food Chem., 2015, 173, 1228-1235.

33. Preedy, V.R. Essential Oils in Food Preservation, Flavor and Safety; London, UK, Academic Press, Elsevier., 2016.

34. Garg, S.C.; Jain R. J. Essent. Oil Res., 1992, 4, 601-606.

35. Kumar R.; Singh S.; Kulshrestha, R. Indian Perfumer., 2007, 51, 55-56.

36. Thanh, L.; Dung, N. X.; Luu H. V. J. Essent. Oil-Bear Plants., 2002, 5, 38-42.

37. Kumar R.; Singh S.; Agarwal, S.C. Indian Perfumer., 2009, 53, 38-40.

38. Bagamboula, C.F.; Uyttendaele, M.; Debevere, J. Food Microbiol., 2004, 21, 33-42.

39. Moore, S. J.; Hill, N.; Ruiz, C.; Cameron, M.M. J. Med. Entomol., 2007, 44, 624-630.

40. Yang, Y. C.; Lee, E. H.; Lee, H. S.; Lee, D. K.; Ahn, Y. J. J. Am. Mosq. Control Assoc., 2004, 20, 146-149. 